\title{
Mentorship experiences in a group of occupational therapy leaders.
}

\author{
Ruth Levine Schemm \\ Thomas Jefferson University \\ Theodore Bross \\ Thomas Jefferson University
}

Follow this and additional works at: https://jdc.jefferson.edu/otfp

Part of the Occupational Therapy Commons

Let us know how access to this document benefits you

\section{Recommended Citation}

Schemm, Ruth Levine and Bross, Theodore, "Mentorship experiences in a group of occupational therapy leaders." (1995). Department of Occupational Therapy Faculty Papers. Paper 38.

https://jdc.jefferson.edu/otfp/38

This Article is brought to you for free and open access by the Jefferson Digital Commons. The Jefferson Digital Commons is a service of Thomas Jefferson University's Center for Teaching and Learning (CTL). The Commons is a showcase for Jefferson books and journals, peer-reviewed scholarly publications, unique historical collections from the University archives, and teaching tools. The Jefferson Digital Commons allows researchers and interested readers anywhere in the world to learn about and keep up to date with Jefferson scholarship. This article has been accepted for inclusion in Department of Occupational Therapy Faculty Papers by an authorized administrator of the Jefferson Digital Commons. For more information, please contact: JeffersonDigitalCommons@jefferson.edu. 


\section{Mentorship Experiences in a Group of Occupational Therapy Leaders}

\author{
Ruth Levine Schemm, Theodore Bross
}

Key Words: leadership $\bullet$ mentor
Ruth Levine Schemm, EdD, OTRL. FAOTA, is Professor and Chairman, Department of Occupational Therapy, Thomas Jefferson University, College of Allied Health Sciences, 130 South 9th Street, Suite 820, Philadelphia, Pennsylvania 19107-5233.

Theodore Bross, Eco. is Manager. Academic Systems, Department of Information Services, Thomas Jefferson University, Philadelphia, Pennsylvania

This article was accepled for publicalion June 8, 1994.
Objectives. The development of occupational therapy leaders is a long-beld goal of many members of the American Occupational Therapy Association and of state associations. The initiation of mentor programs is a common means to accomplish this goal. These programs take time and effort, and, alibough occupational therapists have described bow mentorship programs work in the literaiure, there are few articles that describe the actual mentorship experiences of occupational therapi leaders.

Method. To study the experiences of elected occupational therapy leaders, a 30-item questionnaire was distributed at the anmual meeting of the Committee of State Association Presidents and completed by 53 respondents. Results were analyzed, and cross tabulations were min between selected items.

Results. Respondents were frequently exposed to role models, were assisted by sponsors, were mentored by other occupational therapists, and served as mentors themselves. There was little evidence that the respondents were mentored by bigh-powered individuals who belped launch their careers.

Conclusion. More than half of the respondents were meniored by other occupational therapists, and only $29 \%$ of the respondents reported that they surpassed the slatus and position of their mentors. Plans to initiate mentorship programs sbould include activities that promote powerful leaders who move bevond the status and position of their mentors, so ibat occupational therapists can represent the interests of the profession to others.

$\mathrm{T}$ The need for effective occupational therapy leaders has become more pressing in light of federal and state plans to change the health care industry's social hierarchy and delivery methods (Grossman, 1992; Prestholdt, 1990; Smith, 1992; Robertson, 1992). Occupational therapy association presidents and executive board members have worked hard to develop leaders who remain in the profession; improve the practice and the association; and communicate occupational therapy needs to others, such as universities, school systems, competing professional groups, and reimbursement agencies. This study describes the mentoring experiences of a group of state association presidents. The experiences of these persons, elected to positions of power and authority in occupational therapy professional organizations, are compared with the experiences of other professionals and persons described in the literature of business and other health professions. The results offer an initial understanding of how a group of occupational therapy leaders perceived their experiences as role models, sponsors, mentors, and mentees. The information may stimulate a refinement of existing mentor programs initiated by the state associations and special interest sections, and 
encourage some motivated occupational therapists to seek out mentors who possess the social status, power, and authority to help launch their careers.

\section{Literature Review}

Mentoring is a process in which an older, more experienced person guides and nurtures a younger one. Mentors perform five functions: teacher, sponsor, host and guide, role model, and counselor (Levinson, 1978). Smith (1992) noted that the relationship ranges from an "intense, chemistry-driven relationship to a formalized management development process" (p. 23). "The mentor counsels, critiques, and teaches the mentee how to perform technical, social, and tactical techniques that make organizational survival and advancement casiel Actively engaged in the mentee's performance, the mentor is willing to devote time and thought to the sharing of ideas, while teaching the mentee how to move bevond the present. The mentor offers introductions and recommendations that smooth the mentee's career path and provides advice on carcer options (Kelly, 1978). The mentor makes sure that the mentee is invited to or present at events where the mentce's work can be noticed and calls attention to the mentee's accomplishments so that the work is recognized and, it is hoped, evaluated positively. The mentor observes the mentee in action and offers feedback to further improve the mentee's performance. In return, the mentee reinforces the mentor's ideas, carrying on the mentor's legacy.

Yoder (1990) conceptuali\%ed three aspects of mentoring: (a) a structural role emphasizing the development of a person in an organization, (b) an organizational phenomenon in which a formal program is designed to socialize persons to the culture of the organization or group, and (c) an intense interpersonal relationship between two persons that has parental characteristics. Research indicates that persons who were mentored enjoy more promotions, satisfaction, and compensation (Collins, 1983; Dreher \& Ash, 1990; Fagenson, 1989; Robertson, 1992; Roche, 1979; Smith, 1992; Yoder, 1990).

Rogers (1982) maintained that the essence of mentorship lies in a more experienced person accepting responsibility for helping a less experienced person clevelop and be successful in a profession. The relationship is developmental, and the mentee progresses through stages of growth, beginning with dependence and moving toward independence and individualization (Collins, 1983; Galbraith, Brueggemeyer, \& Manweiler, 1988; Kram, 1983; Roche, 1979; Smith, 1992; Vance, 1982). These developmental stages parallel those of a child gaining independence from parental authority (Collins, 1983; Johnsrud, 1990; Kram, 1983; Pilette, 1980; Yoder, 1990). Because the mentor is frequently motivated by a desire to shape the next generation and assume responsibility for the future, the relationship has paternalistic characteris- tics that are hierarchical and generative. Slowly, the power in the relationship shifts as the mentee gains more status and skills. The relationship is mucually beneficial, accelerating the successful trajectory of the mentee's career and offering the mentor the opportunity to establish a legacy of ideas.

Although the term mentoring began with a business relationship that resembled a parental dyad (Levinson, 1978), it is used more loosely to describe a range of workrelated relationships. Two other types of relationships that are often called mentorships but are not as intense are role model-novice and sponsor-protégé. Role modeling requires identification with the present, "fostering imitation, not self-development" (Smith, 1992, p. 24). A role moclel does not have a strong investment in the novice and may not even be aware of the importance that the novice attributes to his or her role. Learning from the role model's example rather than from any structured learning experience, the novice frequently interprets the role model's behavior without the opportunity to discuss his or her impressions and ideas.

The second type of relationship confused with that of mentor-mentee is that of sponsor-protégé. With a structured relationship initiated by an employer or professional organization, sponsors facilitate entry and advances in the workplace and take responsibility for the protégé's learning. The relationship is designed to promote the goals of the organization so that a newcomer starts off on the right path. Although sponsors perform part of the mentor role, they do not believe they are responsible for launching the careers of their protégés (Rogers, 1982). Because many sponsors are assigned their roles and do not chose their protégés, the close ties present in the mentor-mentee relationship do not develop. Furthermore, in the workplace social hierarchy, sponsors are usually one level above that of their protégés and may not have the power to launch the protégés' careers.

Sponsors fulfill an important function by guiding transitions such as those from nonprofessional to professional, generalist to specialist, and clinician to academician, teaching their charges how to negotiate the power and politics of an organization (Rogers, 1982, 1986). Sponsors are effective role models, counselors, guides, and opportunity finders within the confines of their organizational roles (Cox \& Nkomo, 1991; Whitely, Dougherty, \& Dreher, 1992). Many clinical educators and senior therapists serve as sponsors to fieldwork students or staff member novices. In this period of downsizing and stressful working conditions, sponsorships can prevent turnover, burnout, and ineffective treatments (Freda, 1992)

Like other health professionals, occupational therapists seem comfortable with the concepts of role modeling and sponsorship, and skillfully use many aspects of the mentor role. But congruent with findings from other health professions, evidence suggests that few persons have had a mentor in the real sense of the word (Whitely 
et al., 1992). Reasons for the limited number of occupational therapists who have had high-powered mentors might include issues such as the amount of time needed to foster a mentor relationship, limited exposure and opportunities to meet potential mentors, lack of knowledge about how to obtain a mentor, and discomfort in seeking out another person

Reluctance to seek out a male mentor might be attributed to gender differences for some therapists because $94 \%$ of occupational therapists are women. Tho relationship issue between male mentors and female mentees is not unique to occupational therapists (Cox \& Nkomo, 1991; Ragins, 1989; Ragins \& Cotton, 1991). Ragins (1989) described the organizational and interpersonal barriers that thwart a woman's attempt to develop a mentor relationship and noted the effects of gencler on the relationship. Women may fail to recognize the importance of having mentors, lack time to devote to the relationship, fear that their requests may be misconstrued as sexual advances, experience fewer opportunities to obtain mentors, or be uncomfortable with pursuing a mentor in an assertive manner. The effects of gender were also noted by Hennig and Jardim (1977), who reported less prevalence of mentor relationships among professional women, citing distrust, competitiveness, lack of understanding, and political naivete as possible reasons for differences between men and women. Vance (1982) discussed more positive orientation to mentoring after studying nursing leaders, $83 \%$ of whom reported having one or more mentors and $93 \%$ of whom reported mentoring others.

Ragins and Cotton (1991) found that women perceived more barriers than men did in finding mentors. but women did not differ from men in their reported fears about taking an assertive role in initiating mentor relationships or in their views about who is responsible for making the first move. Experienced mentees, however, reported fewer barriers to obtaining a mentor, so it is likely that once skills are developed, mentees pursue future mentor relationships with greater ease. Ragins (1989) discussed the shortage of female mentors among managers and the complications that gender adds to mentor relationships.

The current occupational therapy mentoring literature is descriptive, offering ideas on how to establish mentorships and develop leaders but leaving questions about the nature of therapists' experiences and mentoring habits (Dunn \& Huss, 1992; Robertson, 1992; Smith 1992). The findings of the present study offer insight into occupational therapy sponsors, mentors, and mentees.

\section{Method}

A 30-item questionnaire based on the work of both $\mathrm{Col}$ lins (1983) and Ballou (1991) was adapted for occupational therapy leaders and distributed at the annual meeting
Table 1

Frequencies and Percentages of Respondents' Highest Level of Education Completed

\begin{tabular}{|c|c|c|}
\hline lovel & Fieguency & Percentage \\
\hline Lonty-level occuparional therapist & 25 & 47 \\
\hline $\begin{array}{l}\text { Batic master i degree oceupational } \\
\text { therapist }\end{array}$ & 7 & 13 \\
\hline Advanced master's degree & 17 & 32 \\
\hline Doctoral ciegree & 1 & 2 \\
\hline Oches & 3 & 6 \\
\hline
\end{tabular}

Nole $N=53$

of the Committee of State Association Presidents (CSAP) in April 1990. Questions regarding age; economic background: marital status; and sponsor, mentor, and mentee experiences were presented. Persons were asked to share details about their mentors such as age and profession. In acldition, they were asked to list the characteristics they would look for in a potential mentee. Respondents were also asked whether a state association mechanism to foster notworking existed. All persons present were asked to fill out the questionnaire, and results were tabulated with Statistical Analysis System (SAS) version 6.07.

\section{Results}

A total of 53 state association presiclents and CSAP officers completed the survey. The ages of respondents ranged from 25 to 55 years, with an average age of approximately 39 years. Forty-seven percent held bachelor's degrees in occupational therapy, and $13.2 \%$ graduated from basic master's degree programs in occupational therapy. Twenty-eight percent were presently enrolled in advanced degree programs (see Table 1). A majority of the respondents $(72 \%)$ had at least 11 years of professional experience in the field, including 10 persons (19\%) who had more than 20 years of experience (see Table 2 ). The average number of years spent in active participation in state associations was 10 , although $21 \%$ of the respondents indicated that they had been active for at least 16 years (see Table 3). Almost all of the respondents (96\%) were women, and $59 \%$ indicated that they were married. The same number (59\%) had children. Sixty-two percent reported having a higher economic background than their parents.

\section{Table 2}

Frequencies and Percentages of Respondents' Number of Years in Occupational Therapy Practice

\begin{tabular}{ccc}
\hline Years & Frequency & Percentage \\
\hline $0-4$ & 1 & 2 \\
$5-10$ & 11 & 21 \\
$11-15$ & 21 & 40 \\
$16-20$ & 10 & 19 \\
$21-25$ & 7 & 13 \\
$>25$ & 3 & 5 \\
\hline
\end{tabular}

Nole, $N=53$ 
Table 3

Frequencies and Percentages of Respondents' Years Active in State Associations

\begin{tabular}{ccc}
\hline Years & Frecpuenc! & Percentige \\
\hline $0-3$ & + & - \\
$4-7$ & $1-$ & 32 \\
$8-11$ & 12 & 23 \\
$12-15$ & 9 & $1-$ \\
$>15$ & 11 & 21 \\
\hline
\end{tabular}

Nole $N=53$

Most of the respondents $(76 \%)$ said they had been mentored: $53 \%$ indicated that the mentoring was (ione bu someone in their state association. Mentors were rypicalls. other occupational therapists $(65 \%)$ or actministrators who were not occupational therapists (12.5\%). A gencral category of "other" was cited by $20 \%$ of the respondents. who listed elucation administator, phusician, parent. reacher, or occupational therapy instructor as the occupation of their mentors (set Table 4 ). Mentors were usually women (70\%) and were okler than the responclents. Only $5 \%$ of the group indicated that they had a younger mencor, whereas $37.5 \%$ reported having a mentor who was at least 16 years older (see lable 5). All respondents who had been mentored indicated that the had beten sponsored on at least one occasion. Many had been sponsored more than once, and $33 \%$ reported having been sponsored at least five times.

Forty percent of the respondents said that they sought out thesir mentors, and $62.5 \%$ inclicated that thes were still in contac with their mentors. Of those who were no longer in contact, none reported that the mentor had ended the relationship, alchough the specific reasons for the current lack of involvement $\left(n=1^{-}\right)$raried. Reasons included change of location $(n=5)$ : mentor left organization ( $n=2)$, job ( $n=5)$, or position ( $n=5)$ : death of mentor $(n=4)$ : and developmental issuce $(n=$ 5) which were reflected in responses such as "it was time," "no longer met my needs." and "we remain friends, but t have moved on, beyond ny mentor " Some respondents listed more than one leason becaluse they had had more than one mentor

Regardless of current involvement, $3^{-5} \%$ inclicated that their relationships lasted for at least 8 years, and $33 \%$ indicated that their relationships lasted 3 vars or kess (see Table 6). Twenty-nine percent of the group believed

Table 4

Frequencies and Percentages of Mentor's Occupation

\begin{tabular}{|c|c|c|}
\hline Occupation & Frecpuency & Perclontage \\
\hline Occupational therapms & 20 & 65 \\
\hline Phusical therapist & 1 & ? \\
\hline Acininistrater & 5 & 13 \\
\hline Oher & 8 & 20) \\
\hline
\end{tabular}

Nole. $N=40$
Table 5

Frequencies and Percentages of Mentor's Age

\begin{tabular}{|c|c|c|}
\hline $\operatorname{sgc}$ & Erepucancl & Pertecontage \\
\hline )ounger thath responckeis & + & 10 \\
\hline 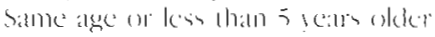 & & \\
\hline thim reypundem & - & 18 \\
\hline 5-10 kall soler than respondent & 13 & 32 \\
\hline 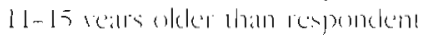 & 8 & 20 \\
\hline$>15$ reat olker thall respondent & 8 & 20 \\
\hline
\end{tabular}

they had surpastad both the status and position of their mencoms. 55\% inclicatcel the hatel not, and 16\% believed their stattus lials equal to that of their mentors

lhe rypes of assistanec offered by the mentor that were most ofen identified by the respondents were support $(95 \%)$, feerlinack $(90 \%)$. knowleclge $(85 \%)$, advice $\left(83^{\circ} \circ\right)$. and introductions (47\%). Almost all respondents selected combinations. with $92 \%$ citing three, four, or five of these typex of ansistance. 'lhe group was equally divided when asked whether their mentors had helped them kam to balance their poofessional and personal roles. lighty-one percent believer that mentor relationships help to socialize new ocupational therapists into the professional network.

Regardless of whether they had been mentored themestes, $72 \%$ of the respondents reported that they had selved as mentors; $79 \%$ of that group indicated that they hat server at least twice. Respondents were asked to idcontif the characteristics they would look for in potential montecs. Eagerness to learn was cited most often $(87 \%)$ followed by an ability to learn from feelback $(83 \%)$, a willingness to share excitement about practice ( $5 \%$ ). and the ability to work hard (70\%) (see Table 7). In acklition, respondents were asked to identify the optimal circunstances under which ther would serve as mentors. Haring an interested mentee (85\%) and time (77\%) were chosen most often, followed by resources $(36 \%)$ and organizational support (13\%).

One respondent expressed a desire to mentor someone who "shows positive potential bevond the' norm that would bencfit societs andor the profession." Another respondent wanted a mentec to "exhibit creativity honest?. and the ability to think independenty and grow from experience-will 'ake off' evencually" Several men-

Table 6

Frequencies and Percentages of Length of Time Spent with Mentor

\begin{tabular}{|c|c|c|}
\hline 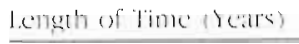 & Frculuenc: & Percentage \\
\hline 1 & 2 & 5 \\
\hline $2-3$ & 11 & 26 \\
\hline+-5 & 9 & 22 \\
\hline $6-{ }^{-}$ & 3 & - \\
\hline$>^{-}$ & 15 & 36 \\
\hline
\end{tabular}

Vole $\quad N=4$ 
Table 7

Frequencies and Percentages of Characteristics Sought in a Potential Mentee

\begin{tabular}{lcc}
\hline \multicolumn{1}{c}{ Characteristic } & Frequenc & Percentage \\
\hline Eager to leirn & 40 & 87 \\
Able to learn fiom feedback & 44 & 83 \\
Shares excitement about practice & 39 & 74 \\
Will do things for you & 37 & 70 \\
Willing to tcach knowledge and skills & 27 & 51 \\
Intelligent & 27 & 51 \\
Expresses graticude & 19 & 36 \\
Gives positive fecolback & 17 & 32 \\
Willing to carly ideats to new arcas & 11 & 21 \\
Work. havd & 3 & 6 \\
\hline
\end{tabular}

Note: Respondens were allowed as chosse multiple characteristics $N=5.3$

tioned that the mentee should be willing to take risks.

Finally, $47 \%$ of the respondents reported that a mechanism existed in their state association to foster networking and $45 \%$ answered that one did not. Eight percent stated that such a mechanism was being developed.

To provicle more detail on key questions, cross tabulations were run between selected items on the instrument. Eighty-cight percent of the occupational therapist mentors were women, whereas $57 \%$ of the mentors who were identified as either administrators or other were men. A chi-square analysis revealed a statistically significant gender difference on this item $\left(\chi^{2}=12.17, p<.005\right)$. Sixty-two percent of the mentors who had been sought out by the respondents were women, and $74 \%$ of the mentors who had not been sought were women, a difference of no statistical significance $\left(\chi^{2}=.57\right)$. Respondents were more likely to still be in contact with their mentors if the mentors had been sought out (75\%) than if the mentors had not been sought out (52\%). The chi-square for this comparison was 2.07 , significant at the .15 level. When the gender of the mentor was compared to whether the respondent had surpassed the mentor's status and position, $32 \%$ of the respondents who had female mentors indicated that they had surpassed their mentors; $27 \%$ of the respondents who had male mentors answered the same way. The chi-square for this comparison was 1.286 , not statistically significant at any meaningful level.

Frequency distributions were calculated between whether respondents had been mentored and the respondents' level of formal education. Of the 17 respondents who had earned an advanced master's degree in occupational therapy, $16(94 \%)$ had been mentored. Sixty-four percent of respondents who held an entry-level occupational therapy degree and $57 \%$ who held a basic master's degree in occupational therapy had becn mentored $\left(\chi^{2}=.54, p<.11\right)$. Finally, of the 38 respondents who indicated that they were not currently enrolled in an advanced degree program, $47 \%$ held an entry-level degree, $11 \%$ held a basic master's degree, $32 \%$ held an advanced master's degree in occupational therapy, and $10 \%$ had an advanced degree in another field.

\section{Discussion}

The purpose of this study was to explore some of the mentoring experiences of occupational therapy leaders and provide some empirical data from which to draw ideas about leadership development in the profession. It is not surprising that almost all of the respondents who had been mentored were women, because the profession as a whole, as well as this particular sample, is dominated by women. Nor is it surprising that $70 \%$ of all mentors themselves were women. What is of interest among these successful occupational therapy leaders is the lack of mentors drawn from outside the profession. Although many sought out their mentors, they were usually other occupational therapists, and few leaders sought out mentors who could further promote their future development.

The finding that most respondents had not surpassed the status and position of their mentors suggests that few were launched in their careers by high-powered persons. What these data do not show is whether the lack of potential mentors was due to a shortage of female mentors within and outside of the profession or whether the shortage was based on therapists' tendency to seek out readily available persons, which led them to therapists who act more like sponsors than mentors.

The findings, combined with respondents' identification of mentoring as an effective means to socializing new therapists into the profession, suggest that aspects of the mentor role are firmly entrenched in the profession but work is needed to promote the career launching and promoting aspects of the mentor role. As one respondent said, "to date whatever happened (in my career) has simply evolved, much is done through role modeling."

It is surprising that a minority of respondents thought that they had either equaled or surpassed the status and position of their mentors, regardless of the mentor's gender. To some extent this finding may signal a warning about the potency of our present leaders' roles as they work to position occupational therapy in the health care delivery system. The mentored group was mature in both age and experience, and as such, could be expected to have advanced further than their responses suggest. One explanation is that some occupational therapists refer to a sponsor or role model as a mentor despite the clear distinctions made between the two roles on the survey instrument. One respondent commented, "I've had several short-term sponsors that have influenced me and opened doors. I'd love a mentor. How do I find one?" Underscoring this point is the finding that fewer than half of the state associations had formal mechanisms to foster networking, a necessary prerequi- 
site to the mentoring process. Furthermore, few state associations encourage networking opportunities with members of other groups or offer leadership training programs for members with more than 10 years of experience.

In addition to adding a formal mentoring system to state associations and special interest groups, state associations could establish a hierarchy of relationships to customize the match between individuals and peer pals (persons with the same rank and status who offer mutual support), sponsors, or mentors. Definitions of each role should be discussed before the relationship is formalized so each person understands the needs and expectations of the other person.

Because the sample used for this study represents a group of persons who were elected to office, these findings cannot be generalized to the profession as a whole. The results do suggest, however, that if state association presidents had difficulty differentiating between a sponsor and a mentor and few used the knowledge and skills of high-powered mentors to launch their own careers, then the potential of mentoring might remain untapped for many therapists who are not active in association activities as well.

\section{References}

Ballou, C. P (1991). The prevalence of mentorship among selected leaders in occupational therapl: Unpublished doctoral dissertation, Texas Women's Universicy, Denton, Texas.

Collins, N. W (1983). Professional women and beir menlors. Englewood Cliffs, NJ: Prentice-Hall.

Cox, T H. \& Nkomo, S. M. (1991). A race and gendergroup analysis of the early career experience of MBAs. Work and Occupations, 18, 431-446.

Dreher, G. F., \& Ash, R. A. (1990). A comparative study of mentoring among men and women in managerial, professional, and rechnical posirions. Journal of Applied Psichologri 75 , 539-546

Dunn, W., \& Huss, A. J. (1992). Personal perspectives on career development: 1nterviews with occupational therapy leaders. Occupational Therapy Practice, 3(3), 1-6.

Fagenson, E. A. (1989). The mentor advantage: Perceived career/job experiences of protégés versus non-protégés. Journal of Organizational Bebalior. 10, 309-320.
Freda, M. (1992). Retaining occuparional therapists in rehabilitation settings: Influential factors. American Joumal of Occupalional Theraps. 46, 240-245.

Galbrairh, I. K., Brueggemeyer, A. E., \& Manweiler, D. L. (1988). Failure to flourish: Indications for mentoring. Pediatric Nursing, 14, 405-408.

Grossman, J. (1992). Commentary: Professionalism in occupational therapy. Occupational Therapy Practice. 3(3), $7-10$.

Hennig, M., \& Jardim, A. (1977). The managerial woman. Garden City, NY: Anchor

Johnsrud, L. K. (1990, April). Mentoring between academic women: The capacity for interdependence. Presented at the Annual Meeting of the American Educational Research Association, Boston.

Kelly, L. Y (1978). Power guide-the mentor relationship. Nursing Outlook. 26, 339

Kram, K. E. (1983). Phases of the mentoring relationship. Academy of 'Management Review. 26, 608-625.

Levinson, D. I (1978). The seasons of a man's life. New York: Knopf.

Pilette. P C. (1980). Mentoring: An encounter of the leaclership kind. Nursing Leadersbip, 3, 22-26.

Prestholdt, C. O. (1990). Modern mentoring: Strategies for developing contemporary nursing leadership. Nursing Administration Quarterly, 15(1), 20-27

Ragins, B. R. (1989). Barriers to mentoring: The female manager"s dilemma. Human Relations, 42, 1-22.

Ragins, B. R. \& Cotton, J. L. (1991). Easier said than done: Gencler differences in perceived barriers to gaining a mentor. Academ.' of Management Journal, 34, 939-951.

Robertson. S. C. (1992). Find a mentor or be one. Rockville. MD: American Occupational Therapy Association.

Roche. G. R. (1979). Much ado about mentors. Harvard Business Retieu, 57, 14-28.

Rogers, J. C. (1982). Sponsorship: Developing leaders for occupational therapy. American Joumal of Occupational Therapy', 36, 309-313.

Rogers, J. C. (1986). Nationally Speaking-Mentoring for career achievement and advancement. American Joumal of Occupational Tberapy, 40, 79-82.

Smith, B. C. (1992). Mentoring: The key to professional growth. Occupational Therapy Practice, 3, 21-28.

Vance, C. N. (1982). The mentor connection. Joumal of Nursing Administration, 12, 7-13.

Whitely, W., Dougherty, T W., \& Dreher, G. F. (1992). Correlates of career-oriented mentoring for early career managers and professionals. Joumal of Organizational Bebavior, 13 . $141-154$

Yoder, L. (1990). Mentoring: A concept analysis. Nursing Administralion. 15, 9-19. 